\title{
Impact of Capital Market Development on the Nigerian Economy: A Post-SAP Analysis
}

\author{
Adeusi, S.O., *Sulaiman, L.A., Azeez, B. A. \\ Ekiti State University, Ado-Ekiti, Ekiti State, Nigeria \\ *sulaimanluq01@gmail.com
}

\begin{abstract}
This paper addresses the impact of capital market development on economic growth and development since the liberalization policy in 1986 to 2010 in Nigeria. It employs Ordinary Least Square (OLS) and Johansen CO-integration estimation techniques. Gross Domestic Product (GDP) was used as measure for economic growth while the capital market development are represented with Market Capitalization (MCAP), Total Value of Transaction (TVT), Total New Issues (TNI), All-Share Index (ALSI) and Total Listing on the NSE (TLT). The result of the study shows that capital market development has not impacted positively on Nigeria economic growth and development due to the relative small size of the market despite its development as a result of the liberalization policy. Thus, it recommends that policies that would encourage domestic as well as foreign investors to participate in the market should be formulated.
\end{abstract}

Keywords: Capital Market Development, Economic Growth, Structural Adjustment Programme (SAP), Nigeria, Ordinary Least Square (OLS) Method, Johansen Co-integration test

\section{Introduction}

The financial system in any economy plays significant role in stimulating economic growth and development. It channels funds efficiently to various economic agents that need them for productive uses. This function is very important for economic growth and development because it creates and makes link between the surplus and deficit units of an economy. The financial system provides this basically through the activities in the financial market. The capital market which is a subset of the financial market provides an avenue for the efficient channelling of long term funds (idle funds) to the users of funds for investment uses from the savers of fund. The other subset being money market, serves as a medium through which short term fund are channelled. In the capital market, the surplus unit of the economy (suppliers of funds) are majorly individuals and corporate bodies as government rarely supply funds to the market while the deficit units consist only of corporate bodies and government since conventionally, individuals cannot access the capital market for funds (Ewah, Esang and Bassey, 2009). It consists of two arms; the primary market which creates a medium for long-term fresh funds to be raised through the issuance of new financial securities, and, secondary market which provide opportunities for the sale and purchase of existing financial securities that have already been traded in the primary market, among investors thereby encouraging investment in financial securities and boosting economic growth.

The institutional framework through which the capital market in Nigeria function include; the Securities and Exchange Commission (SEC), the Nigerian Stock Exchange (NSE), Stock brokers, Issuing houses and Investors. Ewah et al. (2009) noted that, the main objectives of establishing the Nigerian capital market is to mobilize savings from various economic units for economic growth and development, provide adequate liquidity to investors, widen the ownership base of assets as well as the creation of a buoyant private sector and provide alternative source of funds for government. Others are to encourage more efficient allocation of new investments through the price mechanism, encourage more efficient allocation of a given amount of tangible wealth through changes in the composition and ownership of wealth, create a built-in efficiency in the operations and allocation in the financial system to ensure optimal utilization of resources, and promote rapid capital formation. The corporate bodies and governments often require large sum of money to pursue their objectives. It is therefore, usually difficult for them to meet such funding requirements solely from internal sources, hence they often look up to the capital market. This is because the capital market is the ideal source as it provides them the opportunity to have access to the required fund from large number of people and institutions. Thus, the socio-economic function of the capital market is well established. It does not only encourage and mobilize savings but also efficiently allocates such savings to areas of need (Ekineh, 1996). 
Capital market is seen as driver or lubricant that keep turning the wheel of the economy to growth and development because of its imperative function of not just mobilizing long term funds and channelling them to productive investment but also efficiently allocating these funds to projects of best returns to fund owners. This allocative function is critical in determining the overall growth of the economy (Donwa and Odia, 2011). The activities of the capital market affect acquisition of information about firms, liquidity, savings mobilization, risk diversification and corporate control (Anyanwu, 1998). Therefore, by altering the quality of these services, the activities of stock markets can affect the rate of economic growth (Equakun, 2005). This account for why it is so necessary to formulate policies for the market that would assist in facilitating economic growth. The Structural Adjustment Programme (SAP) was one of the major reforms or policies embarked upon in Nigeria with the aim of rectifying the prevailing macro-economic and structural imbalances in the nation's economy, to restructure and diversify the productive base of the economy, lessen dominance of unproductive investment and to achieve fiscal and balance of payment viability. As expected, the capital market was a major aspect of the programme in 1986 when it was introduced. The programme which includes liberalization of the capital market being one of its conditionalities has led to various reforms especially between the late 1980s and early 1990s with the major reforms being the enthronement of market forces as the major price determinants in the market rather than the Securities and Exchange Commission which is the apex regulatory body in the market, the full or partial privatization and commercialization of about 111 public owned enterprises which the NSE plays key role during the offer for sale of their shares (Anyanwu, 1993; Oyefusi and Mogbolu, 2003) and establishment of the Second-Tier Securities Market in 1986.

The introduction of the Structural Adjustment Programme (SAP) in 1986 put pressure on the Nigerian capital market. This was as a result of the high interest rates that accompanied the policy in the money market, which led enterprises in the private sector to patronise the capital market for equity capital. As a result, greater opportunities for private investors who wanted to borrow from the capital market were created (Babalola and Adegbite, 1999). The programme has resulted in a very significant growth of the country's stock market due to the liberalization of the financial sector and the privatization exercise which made the significance of capital market known to investors and companies (Soyode, 1990; Alile, 1996). Ariyo and Adelegan (2005) contend that the capital market liberalization led to the growth of the Nigerian capital market yet its impact at the macro-economy was negligible. In respect to the above, the core of this work will focus on the effects of the Nigeria capital market development on economic growth and development since the adoption of liberalization policy in 1986. The rest of this paper is organised as follows: section two dwells on the overview of the Nigerian Stock Market while section three provides the literature and empirical review. Section four relates the methodology employed, section five will dwell extensively on analysis and discussion of findings while the last section presents the summary, conclusion and recommendations.

Overview of the Nigerian Stock Market: The Nigerian Stock Market can be classified into two sections namely: the primary or new issue market and the secondary market. The primary market or new issue market is a market where new or fresh issues of financial securities are raised by government and corporate bodies. These securities are government bonds and corporate securities like bond and shares. They form the basis of the operations in the secondary market. The major operators in this market are the issuing houses, government and corporate bodies. The secondary market on the other hand is a market that provides an avenue for the purchase and sale of existing securities. It is a market where transfer of ownership of securities takes place. The enterprises do not benefit directly from the operations in this market. The major institution in this market is the Nigerian Stock Exchange (NSE). It comprises of full listing and second-tier securities markets. The Nigerian Stock Exchange was set up in 1959 as the Lagos Stock Exchange based on the report of the Barback Committee. It commenced operations in June 1961 after the enactment of the Lagos Stock Exchange Act 1961 and became the Nigeria Stock Exchange in 1977. The Exchange started operations in 1961 initially with two Federal Government Development Stocks, one preference share and three domestic equities. At the end of 1966, equities increases to six. Government stocks comprised the bulk of the listing with 19 of such securities quoted on the Exchange in 1966 compared with six at the end of 1961 (Nnanna, Englama and Odoko, 2004).

However, in 1985 the NSE introduced Second-Tier Securities Market (SSM), to provide the framework for the listing of small and medium-sized Nigerian companies on the Exchange in order to allow them raise capital. It started operations with one equity in 1985 and grew to twenty three in 1993 and later dropped to 16 in 2005. Following the introduction of Structural Adjustment Programme in 1986 and subsequent deregulation of the capital market in January 1993, the determination of prices of new issue of securities 
that was earlier vested on the Securities and Exchange Commission of Nigeria was now transferred as one of the roles of issuing houses (Olowe, 2004). Transactions in the market recorded increased in the number of listed securities, market capitalization and all-share index. The improved performance was traceable largely to the establishment of the second-tier securities market (SSM) in 1985 and liberalization policy in 1986 which led to the deregulation of interest rates in 1987, coupled with the privatization of some government owned companies in 1991 (Babalola and Adegbite, 1999). The Nigerian Stock Market performs a lot of roles in the development of the economy. The roles according to Muhtar (2009) include the following:

- Providing opportunities for companies to raise funds for expansion of operations leading to increased production, employment and economic growth.

- Creating opportunities for government to finance projects.

- Promoting capital formation by providing the platform for savings to be efficiently mobilised for productive investments.

- Encouraging inflow of foreign capital when foreign companies or investors invest in domestic securities.

- Ensuring an efficient and effective distribution of scare financial resources.

- Creating avenue for the populace to participate in the corporate sector.

\section{Literature Review}

There exists a voluminous literature concerning capital market roles on the economic growth process of a country. The most important and systematic early contribution on the correlation between financial and economic development came from Joseph Schumpeter, who asserted that financial markets being a major indicator of financial development promote economic growth by funding entrepreneurs and more importantly channelling capital efficiently to the entrepreneurs with high return projects (Mishra, Mishra, Mishra and Mishra, 2010). The modern economic analysis on the role of financial development in boosting economic growth started with the seminal works of McKinnon (1973) and Shaw (1973). Both authors drew attention to the widespread 'financial repression' which endangered financial liberalization and deepening, and hence economic growth. Following this, there have been the growing concerns and controversies on the role of the capital market on economic growth and development (Levine and Zervos 1996; Demirgue-kunt and Levine 1996; Nyong 1997; Ariyo and Adelegan 2005; Ewah, et al., 2009; Donwa and Odia, 2011). However, empirical evidence pertaining to effect of Capital markets on economic growth and development has revealed mixed pattern of results providing negative and positive effect. For instance, Emenuga (1998) contended that the stock market is illiquid and blamed the ownership structure in the Nigeria stock market. He concluded that the stock market is small and has few listed companies, low volume of transactions and low market capitalization. Also, Gabriel (2002) found that the capital market in Romania has not significantly contributed to the economic growth of the country.

Ariyo and Adelegan (2005) asserted that the capital market deregulation contributes to the growth of the Nigeria capital market, yet its impact at the macro-economy is quite negligible. Ewah et al. (2009) appraised the effect of the efficiency of the capital market on the economic growth of Nigeria. They discovered that the capital market in Nigeria has the potential of growth-inducing effect but it has not contributed significantly to the economic growth of Nigeria because of low market capitalization, low absorptive capitalization, illiquidity, misappropriation of funds among others. Donwa and Odia (2011), analysed the effect of the Nigerian capital market on her socio-economic development from 1981 to 2008, using the ordinary least square it was found that the capital market indices have not impact significantly on the GDP. However, Levine (1991) postulated that a developed capital market reduces the fear of risk of investors to invest their funds thereby fostering economic growth. This view was supported Levine and Zervos (1996) that a strong positive relationship between stock market development and long-run economic growth. Demiurgic-Kunt and Levine (1996) using pooled cross-country time series data from 44 countries covering the period of 1986 to 1993 found that different performance parameters of stock market are strongly related to other indicators of activity levels of financial, banking, non-banking institutions as well as to insurance companies and pension funds. They concluded that countries with well-developed stock markets tend to also have well-developed financial intermediaries.

Mishra et al. (2010) examined the impact of capital market efficiency on economic growth in India employing multiple regression and using the time series data on market capitalization, total market turnover and stock price index over the period spanning from the first quarter of 1991 to the first quarter of 2010 shows that the capital market in India has the potential of contributing to the economic growth of 
the country and this is as a result of high market capitalization and relatively high market liquidity. Ezeoha, Ebele and Ndi Okereke (2009) analysed the nature of the relationship that exists between stock market development and the level of investment (domestic private investment and foreign private investment) flows in Nigeria. They found that stock market development enhances domestic private investment while it has not been able to encourage the flow of foreign private investment in Nigeria.

\section{Methodology}

The study covers a period of 25 years (1986-2010), 1986 being the year in which liberalization policy was introduced in Nigeria. Data used are sourced from the Central Bank of Nigeria Bulletin and Nigerian Stock Exchange Fact Book of various issues. The Ordinary Least Square (OLS) estimation technique would be employed to assess the short run effects while Johansen co-integrating estimation technique would be employed in order to ascertain the long run effects of the Nigeria capital market indices (Market Capitalization, Total Value of Transaction, Total New Issues, All-Share Index and Total Listing on the NSE) on economic growth and development since the introduction of liberalization policy in 1986.

Model Specification: In this study, the model is based on the modification of the model adopted in the study of Donwa and Odia (2011). The model specifies the endogenous variable (Gross Domestic Product) as a function of Market Capitalization, All Share Index, Total Value of Transaction, Total New Issues and Total Listing on the NSE. The econometric model is specified as follows:

$$
G D P=f(M C A P, A L S I, T V T, T N I, T L T, \mu) \ldots \ldots \ldots \ldots . . .(1)
$$

The explicit form of equation 1 is represented as

Where:

$$
G D P=\beta O+\beta_{1} M C A P+\beta_{2} A L S I+\beta_{3} T V T+\beta_{4} T N T+\beta_{5} T L T_{+} \mu
$$

GDP $=$ Gross Domestic Product

MCAP $=$ Market Capitalization

ALSI $=$ All-Share Index

TVT=Total Value of Transaction

TNI=Total New issues

TLT=Total Listing on the NSE

$\mu=$ Stochastic Disturbance (Error Term)

$\beta_{0}=\quad$ Intercept of relationship in the model/constant

$\beta_{1}-\beta_{5}=$ coefficients of each of the independent variables

By $\log$ linearizing, the model becomes;

$\log (G D P)=\beta_{0}+\beta_{1} \log (M C A P)+\beta_{2} \log (A L S I)+\beta_{3} \log (T V T)+\beta_{4} \log (T N I)+\beta_{5} \log (T L T)+\mu \ldots .$. (3)

Where:

$\log =$ Natural $\log$

From the Equation 3, the model can be specified in a time series form as;

$$
\log (\mathrm{GDP})_{\mathrm{t}}=\beta_{0}+\beta_{1} \log (\mathrm{MCAP}) \mathrm{t}+\beta_{2} \log (\mathrm{ALSI})_{\mathrm{t}}+\beta_{3} \log (\mathrm{TVT})_{\mathrm{t}}+\beta_{4} \log (\mathrm{TNI})+\beta_{5} \log (T L T)_{\mathrm{t}}+\mu
$$

The following are $a$ priori expectations of the coefficient of the model: $=\beta_{1}>0, \beta_{2}>0, \beta_{3}>0, \beta_{4}>0, \beta_{5}>0$.

\section{Result and Discussion}

Presentation of Ordinary Least Square (OLS) Results: Short-Run Analysis: As specified in the previous section, the Ordinary Least Square (OLS) estimation technique is employ in assessing the short run impact of capital market on economic growth in Nigeria focusing on the liberalization period. The

\begin{tabular}{|c|c|c|c|c|c|c|c|c|c|c|}
\hline \multirow{2}{*}{$\begin{array}{l}\text { Dep. } \\
\text { Var. } \\
\text { GDP }\end{array}$} & \multicolumn{3}{|c|}{ Independent Variables } & \multicolumn{7}{|c|}{ Summary of Results } \\
\hline & Constant & MCAP & ALSI & TVT & TNI & TLT & $\mathrm{R}^{2}$ & Adj. $R^{2}$ & F-Cal & $\begin{array}{l}\text { DW- } \\
\text { Stat }\end{array}$ \\
\hline & $\begin{array}{l}-8126 \\
(-0.561)\end{array}$ & $\begin{array}{l}-1.868 \\
(-1.488)\end{array}$ & $\begin{array}{l}231.101 \\
(1.963)\end{array}$ & $\begin{array}{l}3.915 \\
(0.932)\end{array}$ & $\begin{array}{l}16.857^{*} \\
(2.910)\end{array}$ & $\begin{array}{l}37518.93 \\
(0.678)\end{array}$ & 0.896 & 0.871 & $32.86^{*}$ & 1.124 \\
\hline
\end{tabular}
table below shows the summary of the result.

Table 1: Summary of OLS Results

Source: Author's Computation

Note: - T-statistics are stated in parenthesis and * means significant at 5\% significance level. 
From the table above OLS results, it could be inferred that the constant parameter is inversely related to GDP. This implies that even when other variables are held constant the GDP will still reduce by the value of -812676. The Market Capitalization (MCAP) is also inversely related with the coefficient of -1.86834 to GDP. All Share Index as a measure of capital market development is positively related to GDP with a coefficient value of 231.1017 and this implies that there is a direct relationship between GDP and ALSI in the short run and is also in line with our a priori expectation. Other explanation variables; Total Value of Transaction (TVT), Total New Issues (TNI) and Total Listing on the NSE (TLT) are also positively related with GDP. The short run equilibrium relationship between TVT, TNI, TLT and GDP conforms to the $a$ priori expectation. The relationship shows that a unit increase in TVT, TNI, and TLT will cause GDP to rise by $3.91559,16.85745$ and 37518.93 respectively. It can be deduced that only TNI is statistically significant in the model. Also, the coefficient of multiple determination $\left(\mathrm{R}^{2}\right)$ which is used to test the goodness of fit is $89.64 \%$ indicating that $89.64 \%$ of variations or changes in GDP can be determine by all the variables used to proxy capital market development (Market Capitalization, All-Share Index, Total Value of Transaction, Total New Issues and Total Listing on the NSE) while the remaining $10.36 \%$ can be explained by the error term or variables outside the model. The F-statistics is also significant at 5\% indicating the significance of the whole model.

Unit Root Test: The co-integration analysis is subject to the integration order of time series. The integration orders of variables for this study are examined by Augmented Dickey - Fuller (ADF) unit root test. According to ADF unit root test as shown in Table 2, it can be seen that all the variables are not stationary at level except GDP, at first difference all are stationary except GDP and at second difference, and all the time series data (variables) are stationary. For consistency sake, all the series were considered as I(2) and taken at their second difference in the analysis.

Table 2: Unit Root Test (ADF)

\begin{tabular}{llcc}
\hline VARIABLES & LEVEL & 1 $^{\text {ST }}$ DIFFERENCE & 2 $^{\text {ND }}$ DIFFERENCE \\
\hline GDP & $3.348^{* *}$ & -0.718 & $-3.122^{* *}$ \\
MCAP & -0.442 & $-4.875^{*}$ & $-6.915^{*}$ \\
ALSI & -1.326 & $-4.806^{*}$ & $-7.023^{*}$ \\
TVT & -1.186 & $-4.394^{*}$ & $-9.929^{*}$ \\
TNI & -0.051 & $-2.648^{* *}$ & $-4.847^{*}$ \\
TLT & -1.806 & $-4.629^{*}$ & $-6.213^{*}$ \\
\hline
\end{tabular}

**, $\left({ }^{*}\right)$ respectively show significance at $5 \%$ and (1\%) level.

Source: Author's Calculation

Co-Integration Test: According to the unit root result all the series have same integrating level, that is, the second difference, making co-integration applicable on the analysis. As explained in the previous section, the Johansen co-integration technique will be employ in ascertaining the number of long run equilibrium relationships or co-integrating vectors among the variables and how the capital market has affected economic growth in the long-run, since the introduction of liberalization policy in Nigeria. Note that when series are found to be integrated of the same order, such as me(2) as in this study, it implies that an equilibrium relationship exists among the variables. The table below shows the result of the trace test, which indicates that 4 co-integrating equations exists among the variables at $5 \%$ significance level.

Table 3: Trace test

\begin{tabular}{lrlc}
\hline Hypothesized No, of CE(s) & Eigen value & Trace statistic & 5\% critical value \\
\hline $\mathrm{r}=0^{*}$ & 0.9818 & 191.37 & 94.15 \\
$\mathrm{r} \leq 1^{*}$ & 0.8629 & 99.19 & 68.52 \\
$\mathrm{r} \leq 2^{*}$ & 0.6212 & 53.49 & 47.21 \\
$\mathrm{r} \leq 3^{*}$ & 0.5869 & 31.16 & 29.68 \\
$\mathrm{r} \leq 4$ & 0.2976 & 10.82 & 15.41 \\
\hline
\end{tabular}

* denotes rejection of the hypothesis at the $5 \%$ level.

The long run or normalized co-integrating equation is presented as:

GDP=-1.1765MCAP $-249.294 A L S I-89.497 T V T+63.187 T N I-21699.83 T L T+3743113$

$\begin{array}{lllll}\text { (0.6427) (189.186) (18.44) (8007.4) } & \text { (18.067) }\end{array}$

Note: standard errors statistics are stated in parentheses. 
From the long run equation above, it can be derived that all the variables are not in conformity with the $a$ priori expectation because they are inversely related (negatively signed) except TNI which is positively signed. Also when all the independent variables are kept constant, the value of GDP will increase by 3743113 units. A unit increase in MCAP will reduce GDP by 1.1765 and a unit decrease will boost GDP by same value. The coefficient of ALSI is 249.294, indicating that a unit increase in the variable will reduce GDP by same value and vice versa. Also, GDP will be reduced by 89.497 units with a unit increase in TVT and vice versa. A unit increase in TNI and TLT will increase and decrease GDP by 63.187 and 21699.83 respectively and vice versa. Using the standard error test, all the variables are statistically significant except MCAP.

Implication of Findings: The hub of the study is to determine the impact of capital market development on the Nigerian economy in the post SAP era. A vivid observation of the results shows that all the explanatory variables are negatively related to GDP except TNI which is positively related to GDP. Theoretically it is belief that when the capital market develops the economy should be affected positively as specified in the priory expectation. However, the reverse is the case in this study which could be as result of the current state of Nigerian capital market. The inability of the capital market in Nigeria to have impacted positively on economic growth has been ascribed to relative small sized of the market, low market capitalization (Babalola and Adegbite, 1999), low absorptive capitalization, illiquidity among others when compared to other developing economies (Ariyo and Adelegan, 2005). Similarly, other policies measure should also accompany the liberalization measure to really ensure that the intended results of liberalization are attained. Also, the market under liberalization policy has witnessed positive development (Soyode, 1990; Alile, 1996) with increased total value of transactions coupled with increment in the number of listed securities, companies, market capitalization, price index and modernization of its facilities (Babalola and Adegbite, 1998) but when compared with other emerging economies they are still low and this is further exposed in this study as performance indices of the capital market in Nigeria have not positively impacted on her economic growth. This findings is in line with the assertions of Emenuga (1998), Babalola and Adegbite (1999) and Ariyo and Adelegan (2005).

\section{Conclusion and Recommendation}

The study investigates the impact of capital market development on the Nigerian economic development since the adoption of liberalization policy (1986 to 2010). The study employed Johansen co-integration and OLS estimation techniques. The ADF was employed in testing for the stationary of the variables and the hypothesis of non-stationary was rejected at second difference. The main findings from this study indicate that capital market liberalization in Nigeria has not affected her economy significantly. The short run result indicates that all the independent variables except Total New Issues are statistically insignificant though they are having positive relationships except Market Capitalization with GDP while in the long run; all the independent variables are statistically significant except Market capitalization. Hence, it can be said that it has not justify the assertion of McKinnon (1973) and Shaw (1973) on financial liberalization. In light of the findings of this study, the following recommendations were made;

- The market capitalization and transactions in the market should be improved upon and this can be done by encouraging and attracting more foreign and private investors to invest in the market.

- More products should be developed and be traded on the market, as this will enhance the growth of the economy.

- Operations in the market should be open and transparent and market abuse should be totally removed.

- Regulatory authorities should also restore confidence in the market by enacting laws that would ensure trading transparency.

- The monetary should implement policies that increase the flow of investible funds within and outside the country.

It is believed that if the above, recommendations were judiciously followed the effect of capital market development in the post SAP era will be actualized in Nigeria. 


\section{References}

Alile, H. I. (1996). The role of the Capital Market in Africa's Economic Deve1opment in S. Mensah (Ed.), Rector Press Limited, Massachusetts, 180 - 195.

Ariyo, A. \& Adelegan, 0. (2005). Assessing the Impact of Capital Market Reforms in Nigeria: An incremental Approach. Paper presented at the 46th Annual Conference of the Nigeria Economic Society, Lagos, August.

Anyanwu, J. C. (1993). Monetary Economics Theory, Policy and Institutions, Hybrid Publishers Ltd., pp. $247-274$.

Anyanwu, J. C. (1998). Stock Market Development and Nigerian Economic Growth. Nigerian Financial Review, 2, 6-13.

Babalola, J. A. \& Adegbite, M. A. (1999). The Performance of the Nigerian Capital Market Since Deregulation in 1986. CBN Economic \& Financial Review, 39(1), 1-19.

Demirgue-Kunt, A. \& Levin, R. (1996). Stock Market Development and Financial Intermediaries: Stylized Facts. The World bank Economic Review, 10(2), 241-265.

Demirgue Kunt, A. \& Levin, R. (1996). Stock Market, Corporate Finance and Economic Growth: An Overview. The World Bank Review, 10(2), 223-239.

Donwa, P. \& Odia, J. (2010). An Empirical Analysis of the Impact of the Nigerian Capital Market on Her Socio-economic Development. Journal of Social Sciences, 24(2), 135-142.

Emenuga, C. (1998). The Nigeria Capital Market and Nigeria's Economic Performance. Proceedings of the One-day Seminar Held at the Nigerian Institute of International Affairs, Lagos.

Ekineh, S. D. (1996). The Securities and Exchange Commission and Investor Protection in the Capital Market. Security Market Journal, 9, 1 - 86.

Equakun, C. O. (2005). The Nigerian Capital Market: Impact on Economic Growth, Unpublished Master's Thesis, University of Benin, Benin City.

Ewah, S. O. E., Esang, A. E. \& Bassey, J. U. (2009). Appraisal of Capital Market Efficiency on Economic Growth in Nigeria. International Journal of Business and Management, 4, 219-225.

Ezeoha, A., Ebele, O. \& Ndi-Okereke, O. (2009). Stock Market Development and Private Investment Growth in Nigeria. Journal of Sustainable Development in Africa, 11(2),

Gabriel, B. (2002). Investment Banking: Old and New Challenges, in Financial Services in the Evolving Global Marketplace, edited by E. Lyn and G. Papaioannou: Hofstra University Press, Hempstead, New York.

Levine, R. (1991). Stock Markets, Growth and Tax Policy. Journal of Finance, XLVI, 1445-1465.

Levine, R. \& Zervos, S. (1996). Stock Market Development and Long-run Growth. The World Bank Economic Review, 10(3), 323 - 339.

Muhtar, M. (2009). Developing Capital Markets. Arab-America-Asia-Africa Business Summit, Dubai, February 4-5.

Mishra, P. K., Mishra, U. S., Mishra, B. R. \& Mishra, P. (2010). Capital Market Efficiency and Economic Growth: The Case of India. European Journal of Economics, Finance and Administrative Sciences, 27, 1450-2275.

McKinnon, R. I. (1973). Money and Capital in Economic Development, Brooking Institution, Washington DC.

Nnanna, O. J., Englama, A. \& Odoko, F. O. (2004). Financial Markets in Nigeria. Central Bank of Nigeria Economic and Financial Review, 47(7), 11-23.

Nyong, M. O. (1997). Capital Market Development and Long run Economic Growth: Theory, Evidence and Analysis. First Bank Review, 4, 13-38.

Olowe, R. A. (2004). The Impact of Deregulation on the Behaviour of Industry Returns on the Nigerian Stock Exchange. Proceedings of the Annual Conference of the Nigeria Society for Financial Research (NSFR), Department of Business Administration, University of Lagos, November $10^{\text {th }}$. $12^{\text {th }}$.

Oyefusi, S. A. \& Mogbolu, R. O. (2003). Nigeria and the Structural Adjustment Programme, in: Iyoha M. A. \& Itsede C. O. (Eds.): Nigeria Economy Structure, Growth and Development, Benin City: Mindex Publishing, 387-402.

Shaw, E. S. (1973). Financial Deepening in Economic Development. Oxford University Press, New York.

Soyode, A. (1990). The role of capital market in economic development in Nigeria. Security Market Journal, 6(2). 